\author{
奥田 潔・上野山賀久・作本 亮介 \\ 岡山大学農学部動物内分泌学教室 $\mathbf{T} 700-8530$ 岡山市津島中 1-1-1
}

\begin{abstract}
要 約 妊娠が成立し維持されていくためには，卵巣および子宮が正常に機能していることが必要である．とり わけ，黄体から分泌されるプロジェステロンは妊娠の成立と維持に必須のホルモンであり，その分泌調節機構の 解明は不娃症の新しい診断法や生殖の人為的制御法の開発にきわめて重要な意義を有する．黄体のプロジェステ ロン分泌をはじめとする内分泌機能が下垂体や子宮から分泌される内分泌ホルモンにより支配されているのはい うまでもない，しかし，黄体がプロジェステロン以外に多くの生理活性物質を合成分泌していることが明らかに され，さらに，それらの特異的なレセプターの存在が黄体に証明されたことから，オートクライン，パラクライ ン機構による局所的な機能調節機構の存在していることが示朘されている. 黄体内局所調節因子に関するこれま での知見を集約すると，種々の因子は直接的あるいは，間接的に黄体のプロジェステロン分泌調節に関与してい ることが明らかにされつつある.さらに, 局所因子間における相互作用の存在も示唆されている. 黄体内局所調 節因子は周期性黄体のみならず，妊娠黄体の機能維持に関しても何らかの重要な役割を果たしていると考えられ る. キーワード : Corpus luteum, Intra-luteal regulators, Oxytocin, Progesterone, Prostaglandins.
\end{abstract}

(Journal of Reproduction and Development, $43: \mathrm{j} 65-\mathrm{j} 73,1997)$

\section{はじめに}

黄体が妊娠の維持に必要であることは，黄体を除去 すると妊娠が中断されることを示したFrankel [1] のウ サギを用いた実験ではじめて報告された。その後，妊 娠ウサギの卵巣を除去しても，黄体の脂溶性抽出物を 投与することにより，妊娠が数日間維持されることが 報告され [2]，やがて，妊娠の成立に重要な役割を有 するその物質はプロジェステロン（P4）と命名された． P4 は子宮内膜の着床性堌殖を誘起するとともに，筋層 の自発的収縮を抑制して，胚の着床に適した子宮環境 を構築し，妊娠の成立維持に非常に重要な役割を果た している.

本稿では，妊娠成立のための黄体の主たる機能であ
る P4 合成の調節機構について, 外的支配（下垂体なら びに子宮）および内的支配（黄体内におけるオートク ライン，パラクライン）の観点から反笣動物をモデル として考察する.

\section{下垂体ならびに子宮による黄体機能の制御}

図 1 にウシ卵巣の周期性について示した。排卵から黄 体の形成，コらにその機能維持には下垂体に由来する 性腺刺激ホルモン，すなわち卵胞刺激ホルモン（FSH） および，黄体形成ホルモン（LH）が中枢的な役割をは たしている．FSHの作用により卵胞が発育すると顆粒 層細胞からのエストラジオール産生が増大し，LHの一 過性の放出（LHサージ）が誘起される。LHサージ後 の排卵とともに，卵胞を構成していた卵胞内膜細胞と 


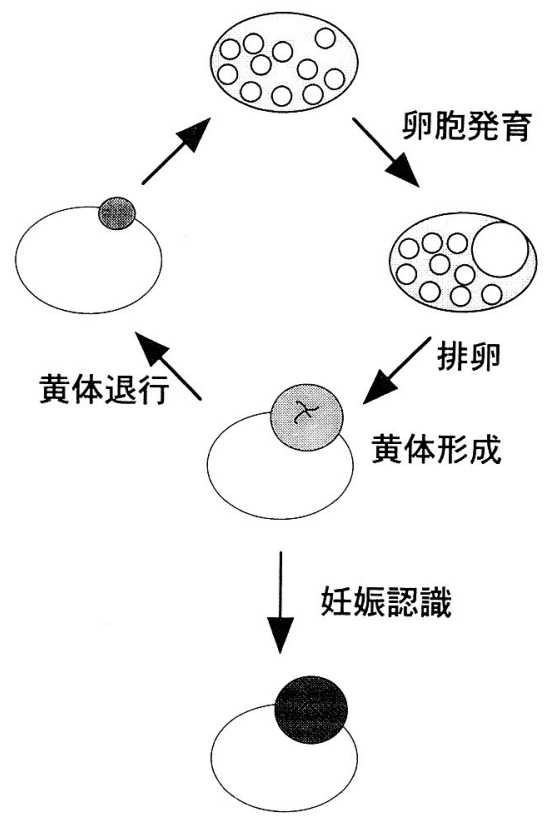

図1. 卵巣の周期性。ウシ卵巣では通常一つの 卵胞から排卵が起こり，黄体が形成され る。妊娠が成立しない場合黄体は退行す るが，母体が妊娠を認識すると黄体退行 が阻止され，奸娠黄体として存続する。
顆粒層細胞の両者から分化した黄体細胞が急速に分裂増 殖し，黄体が形成される。その後，黄体は黄体期中期ま でその大きさとともにP4分泌量を増し，妊娠成立のた めの準備を整えるが，妊娠が成立しない場合ウシでは発 情周期の18日頃には急速に機能を失い，21日には退行 する。黄体退行は，子宮内膜から分泌されるプロス夕グ ランジン (PG) $F_{2 \alpha}$ が子宮静脈と卵巣動脈間の対向流機 構により黄体に作用して起こることが知られているが, $\mathrm{PGF}_{2 \alpha}$ の黄体における作用機構は充分には明らかにされ ていない，一方，妊張が成立した場合には受胎産物の一 部である栄養膜細胞から産生されるインターフェロン （IFN- $\tau ）$ をシグナルとする母体の妊娠認識機構により， 黄体退行が阻止され [3], 分娩に至るまでP4 分泌機能 を維持しながら黄体の存続することが知られている。し かしながら，妊娠黄体のP4分泌機能を維持させる機構 は明らかにされていない。

\section{卵巣内機能調節機構}

1980 年以降のホルモン測定法の改善やレセプターに 関する研究の発展, さらに分子生物学的研究手法の開発

表 1. 卵巣内で合成される生理活性物質とそのレセプターの存在，プ

\begin{tabular}{|c|c|c|c|}
\hline & & レセプター & P4分泌におよぼす影響 \\
\hline \multirow[t]{3}{*}{ Peptidies } & OT & $++^{[14-16]}$ & 促進 ${ }^{[17,18,66]}$. 抑制 ${ }^{[66,67]}$ \\
\hline & AVP & $+{ }^{11}$ & ? \\
\hline & ET-1 & $+{ }^{[21]}$ & 促進 ${ }^{2)} \cdot$ 抑制 ${ }^{[21]}$ \\
\hline \multirow[t]{6}{*}{ Eicosanoids } & $\mathrm{PGF}_{2 \alpha}$ & $+[31,32,44]$ & 促進 ${ }^{[33,34]}$ \\
\hline & $\mathrm{PGE}_{2}$ & $+{ }^{[44]}$ & 促進 ${ }^{[38,39]}$ \\
\hline & $\mathrm{PGI}_{2}$ & $+{ }^{[44]}$ & 促進 ${ }^{[39]}$ \\
\hline & HETES & $?$ & 抑制 ${ }^{[41]}$ \\
\hline & LTs & $+[43,44]$ & 抑制 ${ }^{[45]}$ \\
\hline & TXs & $+{ }^{[42]}$ & 促進 ${ }^{[42]}$ \\
\hline \multirow[t]{7}{*}{ Growth factors } & IGF-I & $+{ }^{[47]}$ & 促進 ${ }^{[53]}$ \\
\hline & IGF-II & $+{ }^{[47]}$ & 效果なし ${ }^{[53]}$ \\
\hline & EGF & $+[51]$ & $?$ \\
\hline & $\mathrm{TGF} \alpha$ & $+[51]$ & $?$ \\
\hline & TGF $\beta$ & $?$ & 促進/抑制 ${ }^{[52]}$ \\
\hline & bFGF & $+[49]$ & 促進/効果なし ${ }^{[52]}$ \\
\hline & NGF & $?$ & 促進/抑制 \\
\hline \multirow[t]{3}{*}{ Cytokines } & $\mathrm{TNF} \alpha$ & $+{ }^{2}$ & 抑制 [57.59] \\
\hline & IL-1 & $?$ & 抑制 [58, 59] \\
\hline & IFN- $\gamma$ & $?$ & 抑制 [56, 59] \\
\hline \multirow[t]{4}{*}{ Neurotransmitter } & NA & $+{ }^{[64]}$ & 促進 ${ }^{[61]}$ \\
\hline & NPY & $?$ & 促進 ${ }^{[65]}$ \\
\hline & SP & $?$ & 促進 ${ }^{[65]}$ \\
\hline & VIP & $?$ & 促進 ${ }^{[65]}$ \\
\hline
\end{tabular}

1) 坂本和一博士（筑波大）未発表.

2) 未発表 
などから，卵巣においてステロイドホルモン以外に成長 因子を含む多くのペプチドホルモンおよびプロス夕グラ ンジン類が合成分泌されること，さらに，特異的なレセ プターが卵巣に存在することが明らかにされ，これら生 理活性物質の卵巣内における生理的役割が解明されつつ ある，その結果，性腺刺激ホルモンや子宮内膜から分泌 される $\mathrm{PGF}_{2 \alpha}$ のように血流を介して作用する古典的な 内分泌機構に加えて，黄体内，卵胞内あるいは卵胞-黄 体間における局所的な調節機構により卵胞および黄体の 機能が調節されている可能性が示されつつある.

表1に黄体で合成されることが明らかにされている生 理活性物質をまとめた．幾つかの物質についてはレセプ ターの存在が明らかにされている。またレセプターの 存在は確かめられていないものの，P4 分泌に対する影 響がすでに明らかにされている生理活性物質も存在して いる．以下にこれらの物質の生理作用やレセプターの局 在などについて述べる.

\section{I. ペプチドホルモン}

\section{I-I. オキシトシン $(\mathrm{OT})$}

OTの発情周期調節への関与は，排卵直後のウシに一 週間にわたり毎日一回 OTを投与すると発情周期が短縮 されることで初めて明らかにされた [4]. さらに，彼ら はこのOTの作用は子宮を除去することにより完全に阻 害されることを見いだし，OT投与による発情周期の短 縮は子宮を介していることを示唆した $[4]$ ．その後， OTの能動免疫処理によりヒツジで発情周期の延長する こと [5], さらに，黄体期初期および，後期にOTを投 与すると末梢血中の $\mathrm{PGF}_{2}$ 濃度の上昇することがウシ で報告された [6]。また，Flintと Sheldrick [7] は $\mathrm{PGF}_{2 \alpha}$ の投与によって卵巣静脈血中の OT濃度が上昇す ることを示し，さらにその後の実験で黄体退行期に黄体 から分泌されるOTと子宮内膜から分泌される $\mathrm{PGF}_{2 \alpha}$ の 間にポジティブフィードバック機構が成立し, 黄体が退 行することが示唆されている $[8,9]$.

卵巣において OTは顆粒層細胞と黄体細胞を産生母地 とする。顆粒層細胞における OT の産生はLHサージに よる細胞の黄体化にともない急増し $[10]$, その後黄体 においては，黄体期初期から中期にかけて増加する [11]。 また，排卵直前の大卯胞に由来する顆粒層細胞の P4 分 泌をOTが促進することが示され [12], OTの黄体機能 への直接的な関与が示唆されてる. 我々は顆粒層細胞と ともに [13], 発情周期のすべてのステージのウシ黄体 にOTレセプターが存在することを明らかにし, OTが黄
表 2. 黄体におけるオキシトシンの生理作用

\begin{tabular}{|c|c|c|}
\hline 動物種 & 培養方法 & $\mathrm{P} 4^{11}$ 分泌におよぼす影響 \\
\hline \multirow[t]{5}{*}{ ウシ } & $\mathrm{MDS}^{2)}$ & 促進 [17] \\
\hline & 組織培養 & 促進 ${ }^{[18]}$ \\
\hline & 細胞培養 & 低濃度 : 促進 ${ }^{[66]}$ \\
\hline & & $\begin{array}{l}\text { 高濃度：抑制 }{ }^{[66]} \\
\text { 抑制 }\end{array}$ \\
\hline & & 効果なし ${ }^{[18]}$ \\
\hline ヒツジ & 細胞培養 & 効果なし [68] \\
\hline ブタ & 細胞培養 & 抑制 [69] \\
\hline \multirow[t]{5}{*}{ ヒト } & 組織培養 & 抑制 ${ }^{[70]}$ \\
\hline & 細胞培養 & 低濃度 : 促進 ${ }^{[71]}$ \\
\hline & & 高濃度 : 抑制 ${ }^{[71]}$ \\
\hline & & 効果なし ${ }^{[72]}$ \\
\hline & & 刺激 [73] \\
\hline ヒヒ & 細胞培養 & 抑制 ${ }^{[74]}$ \\
\hline ラット & 細胞培養 & 効果なし ${ }^{[75]}$ \\
\hline
\end{tabular}

${ }^{1)} \mathrm{P} 4$ : プロジェステロン.

${ }^{2)}$ MDS: Microdialysis (微透析法).

体内局所調節因子であることを示した [14].

黄体のP4 分泌におよぼすOTの影響について表2にま とめた。 反忽動物の黄体における OTの生理的役割は, そのレセプターの存在が明らかにされているにもかかわ らず $[14-16]$, 充分解明されていない. しかし近年, 細胞培養系では見られないP4 分泌促進作用が，組織培 養系においては明確に発現することが報告されており [17，18]，OTの作用発現には cell-to-cell contact（細胞 間接着あるいは細胞間情報伝達) の必要であることが示 唆され, 細胞外マトリックス等の重要性が示されている. しかしながら, 細胞外マトリックスが黄体機能にどのよ うに影響をおよほしているかは充分明らかにされておら ず，今後の研究が期待される。

I-II. アルギニンバゾプレッシン (AVP)

ウシ黄体にAVP mRNAの存在が報告されているが, その発現量は OTに比べ，1/1000程度である [11]。ま た，AVPの濃度はOT と同様に黄体期中期に高く，妊娠 黄体には認められない [19]. Fuchsら [16] はウシ黄体 に ${ }^{3} \mathrm{H}$ で標識されたAVPの結合部位は認められないと報 告しているが, 最近ウシ黄体にAVPレセプターの mRNAの存在することが見いだされている（坂本和一博 士 (筑波大) 未発表).AVPが黄体のホルモン分泌にお よぼす影響についてはほとんど明らかにされていない。

\section{I-III. エンドセリン（ET-1）}

ET-1は，血管内皮細胞から分泌されるペプチドホル モンであり，強い血管収縮および筋収縮作用を有する。 黄体には多くの血管が含まれ, 血管内皮細胞は黄体を構 
成する全細胞の $50 \%$ 以上を占める $[20]$. ET-1 レセプタ 一には $\mathrm{ET}_{\mathrm{A}}$ と $\mathrm{ET}_{\mathrm{B}}$ という二つのサブタイプがあるが, Girsh ら [21］はウシ黄体細胞に $\mathrm{ET}_{\mathrm{A}}$ レセプターの存在 すること，さらに，ET-1が培養細胞の P4 分泌を抑制す ることを明らかにした．また， $\mathrm{PGF}_{2 \alpha} に よ り$ 培養黄体組 織片からの ET-1 産生が増加するとともに，LHによる $\mathrm{P} 4$ 分泌の刺激作用が阻害されること，この $\mathrm{PGF}_{2 \alpha}$ の作 用は $\mathrm{ET}_{\mathrm{A}}$ レセプターアンタゴニストの存在下に扔いて消 失することを示し， $\mathrm{PGF}_{2 \alpha}$ による黄体退行作用は血管内 皮細胞加分泌されるET-1により媒介される可能性を 示唆した [21]。しかし，我々は血管内皮細胞をほとん ど含まない独自の細胞培養系に扔いて, ET-1 は黄体細 胞からのP4 分泌を促進することを見いだして抢り（図 2 ; 作本＆奥田：未発表), ET-1の生理作用の詳細につ いてはさらなる検討が必要である.

\section{I-IV. インヒビン, アクチビン}

インヒビンは顆粒層細胞で合成され，下垂体からの FSH 分泌を抑制する物質として知られている $[22]$ が， ウシでは卵胞内における局所作用はほとんど明らかにさ れていない，一方，インヒビンの $\beta$-サブユニットの二 量体であるアクチビンは卵胞内局所因子として，ウシ顆 粒層細胞のP4 および， OT 分泌を抑制することが明らか にされている [23].

ヒト黄体に $\alpha-\beta$-サブユニット mRNA の存在が明ら かにされた [24] が, ラット黄体では $\alpha$-サブユニット mRNAの存在は確認されているが, $\beta$-サブユニットは存 在せず [25]，生物活性を有するインヒビンの存在は疑 問視されている，さらに，ウシでは顆粒層細胞に㧍ける $\alpha-, \beta$-サブユニット mRNAの発現は排卵と同時に減少 し，中期黄体抄よび，娃娠黄体にはこれらのmRNAの 存在しないことが明らかにされている [26]. ウシ黄体 に扔けるインヒビン，アクチビンの生理的役割はほとん ど明らかにされていない。

\section{II. エイコサノイド}

\section{II-I. プロスタグランジン $\left(\mathrm{PGF}_{2 \alpha}, \mathrm{PGE}_{2}, \mathrm{PGI}_{2}\right)$}

子宮に由来する $\mathrm{PGF}_{2 \alpha}$ は黄体退行を誘起する物質と してよく知られている [27] が，ウシを含む多くの哺乳 動物の黄体に扔いても $\mathrm{PGF}_{2 \alpha}$ を含むプロスタグランジ ンが産生されている [28，29]．卵巣に扔けるプロス夕 グランジンの産生はOT と同様にLHサージにより誘起 され [30]，その黄体組織中の濃度は初期黄体において 最も高い $[28,29]$. 黄体における $\mathrm{PGF}_{2 \alpha}$ のレセプター 濃度は黄体期を通して変動が少なく $[31 ， 32]$, 幾つか

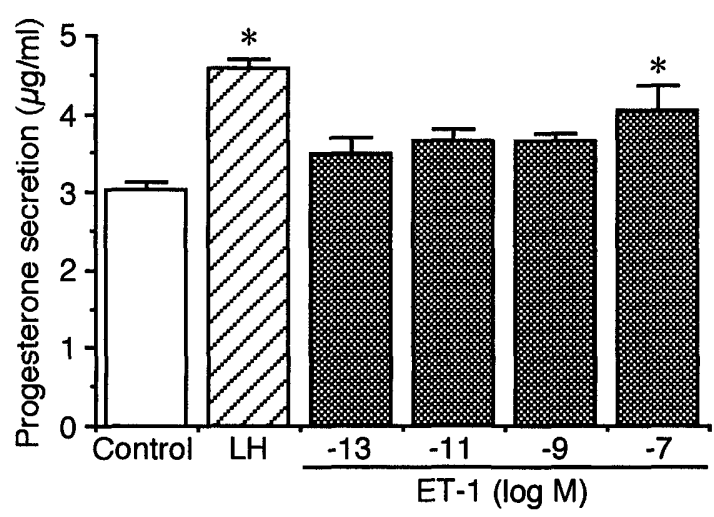

図 2. エンドセリン（ET-1）添加による培養ウシ (中期) 黄体細胞のプロジェステロン分泌量の変化. 灌流 法により黄体組織から血管内皮細胞を大部分除去 した後，黄体細胞を培養した。プロジェステロン 分泌量は $10^{-7}$ M ET-1 の添加により有意に増加し た（* $\mathrm{P}<0.05$ 対無処理区）（作本\& 奥田：未発表).

の in vitroの実験系において $\mathrm{PGF}_{2 \alpha}$ が黄体の $\mathrm{P} 4$ [33，34] およびOT $[35,36]$ 分泌を促進することが報告されて いる. Milvae と Hansel [37］は黄体期初期のウシの子宮 にプロスタグランジンの合成阻害剤であるインドメサシ ンを投与すると，黄体期が短縮することを示し，プロス タグランジンが黄体形成に重要な役割を果たしている可 能性を示唆した。これらのことから, 少なくとも初期黄 体で合成される $\mathrm{PGF}_{2 \alpha}$ は他の黄体刺激性のプロスタグ ランジン（ $\mathrm{PGE}_{2}$ ならびに $\mathrm{PGI}_{2} ）[38,39]$ とともに黄体 の形成とその発達に関与していると考えられる。

また, 我々の研究から黄体に由来する $\mathrm{PGF}_{2 \alpha}$ の生理 作用の一つとして, 黄体の OTレセプタ一濃度の増加に 関与していることが明らかにされている [40].

\section{II-IIＨETEs，ロイコトリエン，トロンボキサン}

黄体ではプロスタグランジンに加え，同じくシクロオ キシゲナーゼ系化合物であるトロンボキサン $(\mathrm{TX})$ ，リ ポオキシゲナーゼ系化合物である HETEs, ロイコトリ エン（LT）といったアラキドン酸代謝産物が合成され る $[41,42]$.さらに, $\mathrm{LTC}_{4} レ$ レプター $[43,44]$, $\mathrm{TXA}_{2}$ レセプター [42] が黄体に存在することが明らか にされている。これらのアラキドン酸代謝産物のうち, HETEs 抒よびLTC 4 はプロスタグランジンと同様に黄体 からの OT 分泌を促進することが報告されている [36]. また, 5-HETE と $\mathrm{LTB}_{4}$ が培養黄体細胞の P4 分泌を抑制 することが示されている $[41 ， 45]$.

以上のことから，黄体で合成されるシクロオキシゲナ 一ゼ系化合物は黄体刺激因子として, リポオキシゲナー ゼ系化合物は黄体機能の抑制因子として作用していると 
推察される。

\section{III. 成長因子}

黄体において多くの成長因子が合成, 分泌され, 細胞 分化増殖作用以外の作用を示すことが明らかにされてい る。ウシ黄体ではIGF-Iの mRNA と蛋白産生 [46] さら にそのレセプターの存在 [47] が報告されている.さら に, bFGF [48－50], EGF [51] についても同様にその 産生とレセプターの存在が報告されている. Miyamoto ら [52] は in vitroの微透析法（MDS）を用いて黄体組 織の内分泌機能におよほすす $\mathrm{bFGF}, \mathrm{NGF}, \mathrm{TGF} \beta$ の影響 について検討し，これらの成長因子が黄体のP4および OT分泌を促進することを明らかにした。しかし，彼ら は血管内皮細胞を含まない黄体細胞培養系ではbFGFの P4 および, OT 分泌に対する刺激作用が消失したのに加 え, NGF およびTGF $\beta$ は 4 および OT 分泌をむしろ抑制 することを見いだした。この培養系の違いによる成長因 子の生理作用の違いは, OT の P4 分泌刺激作用と同様に 細胞間接着あるいは，血管内皮細胞の存在がこれらの作 用発現に関与している可能性を示唆している。また， bFGFとともにレセプターの存在が明らかにされている IGF-Iについては培養黄体細胞のP4 および，OT 分泌を 促進することが報告されている [53] が，EGFについて は黄体における生理的役割は明らかにされていない.

\section{IV. サイトカイン}

サイトカインは排卵時や黄体退行期に卵胞内，黄体内 に侵入するマクロファージなど免疫系の細胞のみなら ず，ウシ顆粒層細胞やヒッジ黄体細胞での産生が確認さ れている [54, 55]. オハイオ州立大学の Pate博士らの 一連の実験からサイトカインが黄体からのプロスタグラ ンジン分泌を促進することが明らかにされている [56-59]. 我々も独自の培養条件下で同様の結果を得 ている（図 3 ; 上野山\&奥田：未発表)。また，彼らは インターロイキン-1（IL-1），腫瘍壊死因子（TNF $\alpha)$, インターフェロン一ガンマ (IFN- $\gamma)$ といったサイトカ インが培養細胞の $\mathrm{P} 4$ 分泌を抑制することを示し, サイ トカインの黄体退行機構への関与を示唆している [56-59]。また，ヒツジ黄体においても， $\mathrm{TNF}_{\alpha}$ および IL-1 が $\mathrm{PGF}_{2 \alpha}$ 分泌を促進することが明らかにされている [60].

サイトカインのレセプターに関する研究はほとんどな

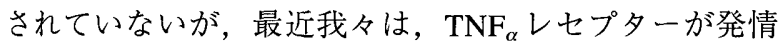
周期を通してウシ黄体に存在することを見いだし（未発

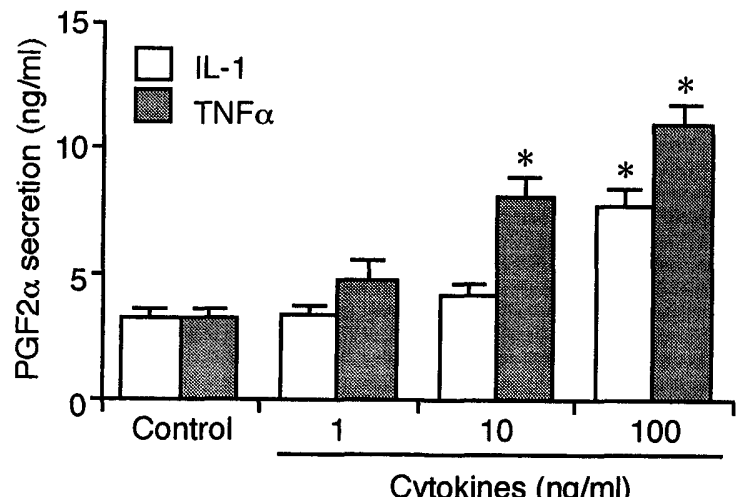

図 3. インターロイキン-1（IL-1），腫瘍壊死因子 $\left(\mathrm{TNF}_{\alpha}\right)$ 添加による培養ウシ (中期) 黄体細胞のプロスタグ ランジン $(\mathrm{PG}) \mathrm{F}_{2 \alpha}$ 分泌量の変化. $\mathrm{PGF}_{2 \alpha}$ 分泌量は $100 \mathrm{ng} / \mathrm{ml} \mathrm{IL-1} \mathrm{および} 10,100 \mathrm{ng} / \mathrm{ml} \mathrm{TNF} \alpha$ の添加 により有意に増加した（*P<0.01 対無処理区 $)$ (上野山\&奥田：未発表)。

表), サイトカインのうち少なくとも $\mathrm{TNF}_{\alpha}$ は, 黄体退 行期以外にも局所因子として黄体機能の調節に関与する と考えられる。

\section{V. 神経伝達物質・神経調節物質}

\section{V-I. ノルアドレナリン}

最近，ウシにノルアドレナリン（NA）を投与すると， 血中の $\mathrm{P} 4, \mathrm{OT}$ 濃度の上昇すること，この作用は $\alpha$ receptorでなく， $\beta$-receptorを介していることが明らかに された [61]. Kotwica ら [62] はウシの腹部大動脈に NAの前駆物質であるドーパミンを投与すると, 頸静脈 血中と比較して尾静脈血中の NA 濃度が有意に高くなる ことを報告している。また，ウシ黄体にdopamine $\beta$ hydroxylase の存在が明らかにされている [63].これら のことは黄体においてNAが合成される可能性を示唆す るものである。さらに, Pestaら [64] は, $\beta$-receptor濃 度は発情周期を通じて血中の $\mathrm{P} 4$ 濃度と平衡して変動す ることを明らかにし，黄体の P4および， OT分泌への NAの関与が強く示唆されている.

\section{V-II. ニューロペプチド}

Miyamoto ら [65] は, neuropeptide Y (NPY), substance P (SP), vasoactive interstinal polypeptide (VIP) が ウシ黄体の $\mathrm{P} 4$ および，OT分泌におよぼす影響を細胞培 養系と細胞間接着のあるMDSで検討し，これらの物質 は細胞培養系ではP4のみを, MDSではP4に加えて OT の分泌を促進することを示した。この培養系によるニュ ーロペプチドの作用の違いについて，彼らはニューロペ 


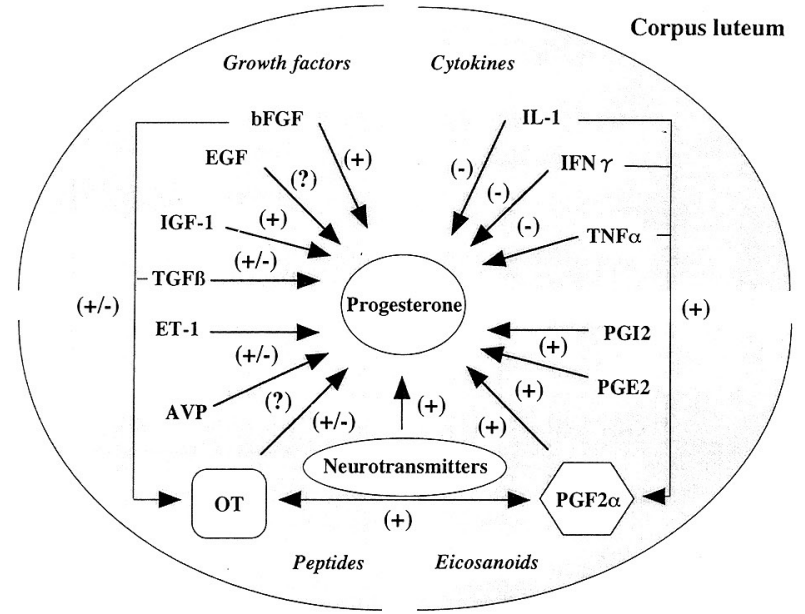

図 4. 主な黄体内局所因子の生理作用。局所因子がプロジェス テロン分泌以外に，互いの分泌を調節していることが次 第に明らかにされつつある。これらの局所因子の相互作 用によって黄体のプロジェステロン分泌が維持されてい ると推察される。

プチドのレセプターが小型黄体細胞に存在し, 細胞間接 着の存在するMDSにおいては小型細胞から大型細胞に ニューロペプチドの作用を伝達できるが，単離された培 養細胞ではこのような情報の伝達が起こらないのではな いかと推察している。しかし，ウシ黄体に扮けるNPY， SP, VIPのレセプターの局在についてはいまだ明らかに されていない.

\section{局所因子間の相互作用と妊娠とのかかわり}

ここまで妊張成立のための必須のホルモンであるP4 の黄体に扔ける合成，分泌が下垂体ならびに，子宮から 分泌される内分泌ホルモンのみならず，黄体で合成され る種々の局所調節因子により制御されていることを概説 した (図 4 参照). 黄体内局所調節機構に関する研究は まだ緒についたばかりで，性腺刺激ホルモンをはじめと する様々な内分泌ホルモンや局所因子間における相互作 用については充分には明らかにされていない.

しかしながら，初期黄体から分泌される $\mathrm{PGF}_{2 \alpha}$ につ いては，局所因子間の相互作用が明らかにされている。 すなわち, $\mathrm{PGF}_{2 \alpha}$ は黄体の $\mathrm{P} 4$ と OT 分泌を促進するとと もに [33-36], OTレセプターを増加させる [40].さ らに，OTがP4分泌を促進することから [17，18]， $\mathrm{PGF}_{2 \alpha}$ による $\mathrm{P} 4$ 分泌の促進は，少なくとも一部におい ては，OTにより媒介されていると推察される（図5). このように局所因子は単独で黄体機能を左右するような 重大な生理的役割を果たしているのではなく, $\mathrm{PGF}_{2 \alpha}$ と

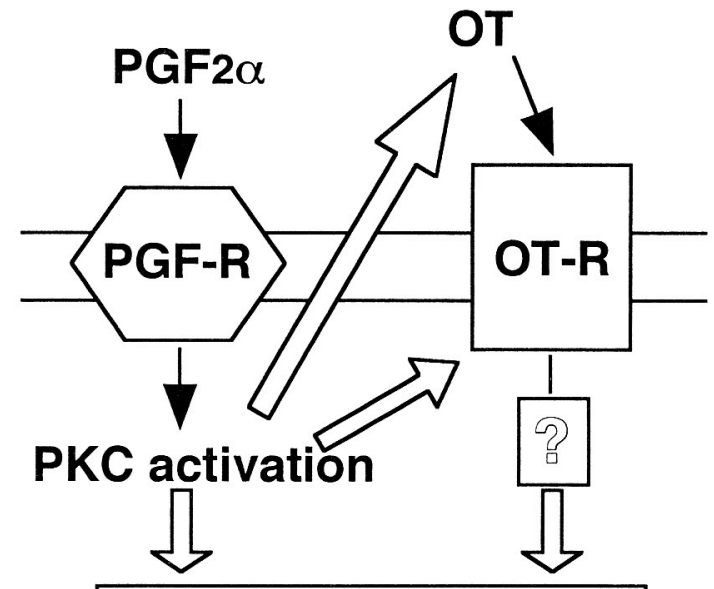

Progesterone secretion

図 5. 黄体で産生されるプロスタグランジン $(\mathrm{PG}) \mathrm{F}_{2 \alpha}$ とオキシトシン (OT) との相互作用. $\mathrm{PGF}_{2 \alpha}$ は その特異的なレセプター（PGF-R）と結合した 後, プロテインキナーゼ ( $\mathrm{PK}) \mathrm{C}$ の活性化を介 してプロジェステロン分泌を促進するとともに， OT 分泌ならびに，そのレセプター（OT-R） 濃 度を増加させる。分泌された OT は OT-R と結合 した後, プロジェステロン分泌を促進すると考 えられる。

OTの間に見られるような相互作用によって，さらには， 複数の因子の種々の組み合わせによって，黄体機能に大 小様々の影響を㧍よぼしていると考えられる。

周期性黄体の形成はLHにより支配されていると言え る。さらに，妊娠黄体は受胎産物の一部である胎児栄養 膜細胞から分泌されるIFN-てによる母体の妊娠認識と, それにともなう黄体退行の阻止を経て成立することが明 らかにされている。しかし, 周期性黄体および妊娠黄体 のP4 分泌の調節機構はいまだ不明な点が多く残されて いる．上に示したように周期性黄体の機能は，少なくと も一部は黄体内局所調節因子により調節されていると考 えられ，この局所調節機構は妊娠黄体の機能維持におい ても重要な役割を有しているのかも知れない。 今後, 周 期性黄体のみならず，妊娠黄体におけるこれらの局所因 子の濃度変化, レセプター発現およびそれらの調節機構 に関する新しい知見が集積されることにより，妊娠成立 とその維持に対する黄体内局所調節機構の重要性が明ら かとなることが期待される.

\section{引用文献}

1. Frankel L. Die Funktion des Corpus luteums. Arch Gynaekol 1903; 38: 438-443.

2. Allen WM, Corner GW. Physiology of the corpus luteum: 
production of special uterine reaction (progestational proliferation) by extracts of corpus luteum. Am J Physiol 1929; 88: 326-334.

3. Roberts RM, Xie S, Mathialagan N. Maternal recognition of pregnancy. Biol Reprod 1996; 54: 294-302.

4. Armstrong DT, Hansel W. Alteration of the bovine estrous cycle with oxytocin. J Dairy Sci 1959; 42: 533-542.

5. Sheldrick EL, Mitchell MD, Flint APF. Delayed luteal regression in ewes immunized against oxytocin. $J$ Reprod Fertil 1980; 59: 37-42.

6. Silvia WJ, Taylor ML. Relationship between uterine secretion of prostaglandin $\mathrm{F}_{2 \alpha}$ induced by oxytocin and endogenous concentrations of estradiol and progesterone at three stages of the bovine estrous cycle. J Anim Sci 1989; 67: 2347-2353.

7. Flint APF, Sheldrick EL. Ovarian secretion of oxytocin is stimulated by prostaglandin. Nature 1982; 297: 587-588.

8. Flint APF, Sheldrick EL. Evidence for a systemic role for ovarian oxytocin in luteal regression in sheep. J Reprod Fertil 1983; 67: 215-225.

9. Schams D, Schallenberger E, Meyer HHD, Bullermann B, Breitinger H-J, Enzenhöfer G, Koll R, Kruip ThAM, Walters DL, Karg H. Ovarian oxytocin during the estrous cycle in cattle. In: Amico JA, Robinson AG (eds.), Oxytocin, Clinical and Laboratory Studies. Amsterdam: Elsevier Biomedical: 1985: 317-344.

10. Voss AK, Fortune JE. Oxytocin/neurophysin-I messenger ribonucleic acid in bovine granulosa cells increases after the luteinizing hormone (LH) surge and is stimulated by LH in vitro. Endocrinology 1992; 131: 2755-2762.

11. Ivell $\mathbf{R}$, Richter $\mathbf{D}$. The gene for the hypothalamic peptide hormone oxytocin is highly expressed in the bovine corpus luteum: biosynthesis, structure and sequence analysis. EMBO J 1984; 3: 2351-2354.

12. Chandrasekher YA, Fortune JE. Effects of oxytocin on steroidogenesis by bovine theca and granulosa cells. Endocrinology 1990; 127: 926-933.

13. Okuda K, Uenoyama Y, Fujita Y, Iga K, Sakamoto K, Kimura T. Functional oxytocin receptors in bovine granulosa cells. Biol Reprod 1997; 56: 625-631.

14. Okuda K, Miyamoto A, Sauerwein H, Schweigert FJ, Schams D. Evidence for oxytocin receptors in cultured bovine luteal cells. Biol Reprod 1992; 46: 1001-1006.

15. Sernia C, Gemmell RT, Thomas WG. Oxytocin receptors in the ovine corpus luteum. JEndocrinol 1989; 121: 117-123.

16. Fuchs A-R, Behrens $\mathbf{O}$, Helmer $\mathbf{H}$, Vangsted A, Ivanisevic $M$, Grifo J, Barros C, Fields M. Oxytocin and vasopressin binding sites in human and bovine ovaries. Am J Obstet Gynecol 1990; 163: 1961-1967.

17. Miyamoto A, Schams D. Oxytocin stimulates progesterone release from microdialyzed bovine corpus luteum in vitro. Biol Reprod 1991; 44: 1163-1170.

18. Sakumoto R, Ando Y, Okuda K. Progesterone release of bovine corpus luteum in response to oxytocin in different culture systems. J Reprod Dev 1996; 42: 199-204.

19. Wathes DC, Swann RW, Pickering BT. Variations in oxytocin, vasopressin and neurophysin concentrations in the bovine ovary during the oestrous cycle and pregnancy. $J$
Reprod Fertil 1984; 71: 551-557.

20. O'Shea JD, Rodgers RJ, D'Occhio MJ. Cellular composition of the cyclic corpus luteum of the cow. I Reprod Fertil 1989; 85: 483-487.

21. Girsh E, Milvae RA, Wang W, Meidan R. Effect of endothelin-1 on bovine luteal cells function: role in prostaglandin $\mathrm{F}_{2 \alpha}$-induced antisteroidogenic action. Endocrinology 1996; 137: 1306-1312.

22. Burger HG, Igarashi M. Inhibin: definition and nomenclature, including related substances. Endocrinology 1988; 122: $1701-1702$.

23. Shukovski K, Findlay JK. Activin-A inhibits oxytocin and progesterone production by preovulatory bovine granulosa cells in vitro. Endocrinology 1990; 126: 2222-2224.

24. Davis SR, Krozowski Z, McLachlan RI, Burger HG. Inhibin gene expression in the human corpus luteum. $J$ Endocrinol 1987; 115: R21-R23.

25. Davis SR, Dench F, Nikolaidis I, Clements JA, Forage RG, Krozowski Z, Burger HG. Inhibin A-subunit gene expression in the ovaries of immature rats is stimulated by pregnant mare serum gonadotropin. Biochem Biophys Res Commun 1986; 138: 1191-1195.

26. Rodgers RJ, Stuchbery SJ, Findlay JK. Inhibin mRNAs in ovine and bovine ovarian follicles and corpora lutea throughout the estrous cycle and gestation. Mol Cell Endocrinol 1989; 62: 95-101.

27. Silvia WJ, Lewis GS, McCracken JA, Thatcher WW, Wilson Jr L. Hormonal regulation of uterine secretion of prostaglandin $\mathrm{F}_{2 \alpha}$ during luteolysis in ruminants. Biol Reprod 1991; 45: 655-663.

28. Milvae RA, Hansel W. Prostacyclin, prostaglandin $\mathbf{F}_{2 \alpha}$ and progesterone production by bovine luteal cells during the estrous cycle. Biol Reprod 1983; 29: 1063-1068.

29. Rodgers RJ, Mitchel MD, Simpson ER. Secretion of progesterone and prostaglandins by cells of bovine corpora lutea from three stages of the luteal phase. J Endocrinol 1988; 118: 121-126.

30. Sirois J. Induction of prostaglandin endoperoxide synthase2 by human chorionic gonadotropin in bovine preovulatory follicles in vivo. Endocrinology 1994; 135: 841-848.

31. Sakamoto K, Miwa K, Ezashi T, Okuda-Ashitaka E, Okuda $\mathbf{K}$, Houtani T, Sugimoto T, Ito S, Hayaishi $\mathbf{O}$. Expression of mRNA encoding the prostaglandin $\mathrm{F}_{2 \alpha}$ receptor in bovine corpora lutea throughout the oestrous cycle and pregnancy. $J$ Reprod Fertil 1995; 103: 99-105.

32. Wiltbank MC, Shiao TF, Bergfelt DR, Ginther OJ Prostaglandin $\mathrm{F}_{2 \alpha}$ receptor in the early bovine corpus luteum. Biol Reprod 1995; 52: 74-78.

33. Michael AE, Abayasekara DRE, Webley GE. The luteotropic actions of prostaglandins $\mathrm{E}_{2}$ and $\mathrm{F}_{2 \alpha}$ on dispersed marmoset luteal cells are differentially mediated via cyclic AMP and protein kinase C. J Endocrinol 1993; 138: 291-298.

34. Miyamoto $\mathbf{A}$, von Lützow $\mathbf{H}$, Schams $\mathbf{D}$. Acute actions of prostaglandin $\mathrm{F}_{2 \alpha}, \mathrm{E}_{2}$ and $\mathrm{I}_{2}$ in microdialyzed bovine corpus luteum in vitro. Biol Reprod 1993; 49: 426-430.

35. Abdelgadir SE, Swanson LV, Oldfield JE, Stormshak F. Prostaglandin $\mathrm{F}_{2 \alpha}$-induced release of oxytocin from bovine corpora lutea in vitro. Biol Reprod 1987; 37: 550-555. 
36. Lafrance M, Hansel W. Role of arachidonic acid and its metabolites in the regulation of progesterone and oxytocin release from bovine corpus luteum. Proc Soc Exp Biol Med 1992; 201: 106-113.

37. Milvae RA, Hansel W. Inhibition of bovine luteal function by indomethacin. JAnim Sci 1985; 60: 528-531.

38. Godkin JD, Black DL, Duby RT. Stimulation of cyclic AMP and progesterone synthesis by $\mathrm{LH}, \mathrm{PGE}_{2}$ and isoproterenol in the bovine CL in vitro. Biol Reprod 1977; 17: 514-518.

39. Fitz TA, Hoyer PB, Niswender GD. Interaction of prostaglandins with subpopulations of ovine luteal cells. I. Stimulation effects of prostaglandin $E_{1}, E_{2}$ and $I_{2}$. Prostaglandins 1984; 28: 119-126.

40. Okuda K, Uenoyama Y, Miyamoto A, Okano A, Schweigert FJ, Schams D. Effects of prostaglandins and oestradiol-17 $\beta$ on oxytocin binding in cultured bovine luteal cells. Reprod Fertil Dev 1995; 7: 1045-1051.

41. Milvae RA, Alila HW, Hansel W. Involvement of lipoxygenase products of arachidonic acid metabolism in bovine luteal function. Biol Reprod 1986; 35: 1210-1215.

42. Lei ZM, Rao ChV, Chakraborty C. Expression of thromboxane $A_{2}$ receptor gene and thromboxane $A_{2}$ synthase in bovine corpora lutea. Biol Reprod 1992; 47: 233-244.

43. Chegini N, Rao ChV. The presence of leukotriene C4-binding sites in bovine corpora lutea of pregnancy. Biol Reprod 1988; 39: 929-935.

44. Chegini N, Lei ZM, Rao ChV, Hansel W. Cellular distribution and cycle phase dependency of gonadotropin and eicosanoid binding sites in bovine corpora lutea. Biol Reprod 1991; 45: 506-513.

45. Yoshimura Y, Nakamura Y, Ichikawa F, Oda T, Jinno M, Ando M, Koyama N, Shiokawa S. Possible involvement of leukotrienes in human luteal function. Acta Endocrinol 1992; 127: $246-251$.

46. Einspanier R, Miyamoto A, Schams D, Müller M, Brem G. Tissue concentration, mRNA expression and stimulation of IGF-I in luteal tissue during the oestrous cycle and pregnancy of cows. J Reprod Fertil 1990; 90: 439-445.

47. Sauerwein H, Miyamoto A, Günther J, Meyer HHD, Schams D. Binding and action of insulin-like growth factors and insulin in bovine luteal tissue during the oestrous cycle. $J$ Reprod Fertil 1992; 96: 103-115.

48. Stirling D, Waterman MR, Simpson ER. Expression of mRNA encoding basic fibroblast growth factor (bFGF) in bovine corpora lutea and cultured luteal cells. J Reprod Fertil 1991; 91: 1-8.

49. Schams D, Miyamoto A, Brückmann A, Sauerwein H, Amselgruber W, Sinowatz F, Gospodarowicz D. Basic fibroblast growth factor and luteal function (location, binding and stimulation of secretion). Biol Reprod 1993; 48(Suppl 1): Abstract 14.

50. Schams D, Amselgruber W, Einspanier R, Sinowatz F, Gospodarowicz D. Localization and tissue concentration of basic fibroblast growth factor in the bovine corpus luteum. Endocrine 1994; 2: 907-912.

51. Okuda K, Uenoyama Y, Hwang K-N, Yamada J, Wakabayashi K. Epidermal growth factor and its receptor in bovine corpus luteum during the estrous cycle. J Reprod Dev 1994; 40:
349-354.

52. Miyamoto A, Okuda K, Schweigert FJ, Schams D. Effects of basic fibroblast growth factor, transforming growth factor- $\beta$ and nerve growth factor on the secretory function of the bovine corpus luteum in vitro. $J$ Endocrinol 1992; 135: 103-114.

53. McArdle CA, Holtorf A-P. Oxytocin and progesterone release from bovine corpus luteal cells in culture: effects of insulin-like growth factor I, insulin, and prostaglandins. Endocrinology 1989; 124: 1278-1286.

54. Roby KF, Terranova PF. Localization of tumor necrosis factor (TNF) in rat and bovine ovary using immunocytochemistry and cell blot: evidence for granulosal production. In: Hirshfield AN (ed.), Growth Factors and the Ovary. New York: Plenum Press; 1989: 273-278.

55. Ji I, Slaughter RG, Ellis JA, Ji TH, Murdoch WJ. Analysis of ovine corpora lutea for tumor necrosis factor mRNA and bioactivity during prostaglandin-induced luteolysis. Mol Cell Endocrinol 1991; 81: 77-80.

56. Fairchild DL, Pate JL. Modulation of bovine luteal cell synthetic capacity by interferon-gamma. Biol Reprod 1991; 44: 357-363.

57. Benyo DF, Pate JL. Tumor necrosis factor- $\alpha$ alters bovine luteal cell synthetic capacity and viability. Endocrinology 1992; 130: 854-860.

58. Townson DH, Pate JL. Regulation of prostaglandin synthesis by interleukin- $1 \beta$ in cultured bovine luteal cells. Biol Reprod 1994; 51: 480-485.

59. Pate JL. Involvement of immune cells in regulation of ovarian function. J Reprod Fertil 1995; 49 (Suppl): 365-377.

60. Miyamoto A, Tashiro Y, Nakatsuka T, Meyer HHD, Taguchi $\mathbf{K}$, Abe N, Fukui Y. Effects of tumor necrosis factor- $\alpha$ and interleukin-1 on local release of progesterone, prostaglandin $\mathrm{F}_{2 \alpha}$ and oxytocin in microdialyzed ovine corpus luteum in vivo. Assist Reprod Tech/Andrology 1995; 8: 21-32.

61. Skarzynski D, Kotwica J. Mechanism of noradrenaline influence on the secretion of ovarian oxytocin and progesterone in conscious cattle. J Reprod Fertil 1993; 97: 419-424.

62. Kotwica J, Jaroszewski J, Skarzynski D, Bogacki M. Involvement of dopamine in bovine corpus luteum secretory functions in conscious cattle. J Reprod Fertil Abstr Ser 1994; 13 ; Abstract 32.

63. Battista PJ, Rexroad CE, Poff JP, Condon WA. Support for a physiological role of endogenous catecholamines in the stimulation of bovine luteal progesterone production. Biol Reprod 1989; 41: 807-812.

64. Pesta M, Muszynska A, Kucharski J, Superata J, Kotwica J. Beta-adrenergic receptors in corpora lutea from different stages of the estrous cycle in conscious and slaughtered cattle. Biol Reprod 1994; 50: 215-221.

65. Miyamoto A, Brückman A, von Lützow $\mathbf{H}$, Schams D. Multiple effects of neuropeptide $Y$, substance $P$ and vasoactive intestinal polypeptide on progesterone and oxytocin release from bovine corpus luteum in vitro. J Endocrinol 1993; 138 : 451-458.

66. Tan GJS, Tweedale R, Biggs JSG. Effects of oxytocin on the bovine corpus luteum of early pregnancy. J Reprod Fertil 
1982; 66: 75-78.

67. Schams D. Ovarian peptides in the cow and sheep. J Reprod Fertil 1989; 37 (Suppl): 225-231.

68. Rodgers RJ, O'Shea JD, Findlay JK. Do small and large luteal cells of the sheep interact in the production of progesterone. J Reprod Fertil 1985; 75: 85-94.

69. Pitzel L, Probst J, Jarry H, Wuttke W. Inhibitory effect of oxytocin and vasopressin on steroid release by cultured porcine luteal cells. Endocrinology 1988; 122: 1780-1785.

70. Bennegard B, Hahlin M, Dennefors B. Antigonadotropic effect of oxytocin on the isolated human corpus luteum. Fertil Steril 1987; 47: 431-435.

71. Tan GJS, Tweedale R, Biggs JSG. Oxytocin may play a role in the control of the human corpus luteum. $J$ Endocrinol 1982; 95: 65-70.

72. Richardson MC, Masson GM. Lack of direct inhibitory action of oxytocin on progesterone production by dispersed cells from human corpus luteum. J Endocrinol 1985; 104: 149-151.

73. Maas S, Jarry H, Teichmann A, Rath W, Kuhn W, Wuttke W. Paracrine actions of oxytocin, prostaglandin $F_{2 \alpha}$, and estradiol within the human corpus luteum. J Clin Endocrinol Metab 1992; 74: 306-312.

74. Khan-Dawood FS, Huang J-C, Dawood-Yusoff M. Baboon corpus luteum oxytocin: an intragonadal peptide modulator of luteal function. Am J Obstet Gynecol 1988; 158: 882-891.

75. Mukhopadhyay AK, Kumar A, Tams R, Bohnet HG, Leidenberger FA. Oxytocin and vasopressin have no effect on progesterone production and cyclic AMP accumulation by rat luteal cells in vitro. J Reprod Fertil 1984; 72: 137-141.

\title{
Corpus Luteum and Its Control by Intra-Luteal Regulators
}

\author{
Kiyoshi OKUDA, Yoshihisa UenoYama, Ryosuke SAKUmoto \\ Laboratory of Reproductive Endocrinology, Faculty of Agriculture, Okayama University, Okayama \\ 700
}

Summary. It is well documented that the corpus luteum is required for a successful pregnancy. The primary function of the corpus luteum is to secrete progesterone, which has several biological effects on target tissues in the reproductive system to prepare them for support of pregnancy or to provide nourishment to the conceptus. In most domestic species including cattle, three organ systems regulate the function of the corpus luteum. The anterior pituitary gland secretes LH, which is the primary hormone responsible for stimulating the secretion of progesterone. The uterus has a luteolytic effect during the late luteal phase of the estrous cycle. This luteolytic effect of the uterus is mediated via secretion of prostaglandin $\mathrm{F}_{2 \alpha}$. Finally, the conceptus has either direct luteotropic or antiluteolytic effects. However, there is increasing evidence for the existence of substances in luteal tissue which are able to act locally, either alone or by modulating the action of the gonadotropins, thus modifying the functions of corpus luteum. The intra-luteal regulators consist of peptides, eicosanoids, growth factors, cytokines, and neurotransmitters. Available data suggest an important role for these substances in the control of luteal function during not only pregnancy but the estrous cycle as well. 